\title{
The role of health tourism in reducing the number of occupational diseases and accidents in the mechanical engineering and metalworking sectors in Latvia
}

\author{
Jelena Lukjanova* \\ ${ }^{1}$ ISMA University, 1 Lomonosova Str., Bld.6, LV-1019, Riga, Latvia
}

\begin{abstract}
In order to ensure successful innovative development of Latvian mechanical engineering and metalworking industry, quality of human resources is one of the important task. First of all, it is necessary to name health of people working in the industry. In Latvia a number of occupational diseases increased, with the greatest growth taking place in manufacturing industry, integral part of which is the engineering and metalworking industry. The problem of accidents at work is also urgent, the number of diseases caused by growing stress. Taking into consideration difficult demographic situation in Latvia and the existing problems in labor market, this situation requires special attention. In the article, the author substantiates the importance and prospects of the development of health tourism as an important factor in maintaining the health and working ability of workers in engineering industry.
\end{abstract}

\section{Introduction}

Engineering and metalworking are one of the leading industries in Latvia. The industry includes the following types of economic activity: Manufacture of basic metals; Manufacture of fabricated metal products, except machinery and equipment; Manufacture of electrical equipment; Manufacture of machinery and equipment n.e.c.; Manufacture of motor vehicles, trailers and semi-trailers; Manufacture of other transport equipment.

Engineering and metalworking is a strategic industry, because, firstly, manufactured products have a high added value, and secondly, industry provides other sectors of national economy with machines, production systems, components and related services, as well as the technologies and knowledge necessary for these industries, thirdly, this industry has a pronounced export orientation. In 2018, the industry provided $18 \%$ of the total turnover of $23 \%$ of total export of manufactured goods. An important element in the development of this sector is its innovation $[1,2]$.

In the transition to an economy based on knowledge and innovations, the quality of human resources is of particular importance. Human resources are a combination of various qualities of people (intellectual abilities, knowledge, skills and competencies, educational

\footnotetext{
${ }^{*}$ Corresponding author: jelena.lukjanova@,isma.lv
} 
level, physical and mental health, etc.) that determine their ability to create tangible and intangible benefits [3]. They are stimulated by innovative personnel management methods $[4,5]$. The incentive systems used in enterprises are of great importance. They affect work efficiency [6]. They also stimulate the innovation of the company, which affects the quality of work [7-10].

Today in Latvia there is the acute problem of increasing number of accidents and occupational diseases. According to Labor Inspectorate, in 2018 in Latvia as whole, work accidents occurred with 2,191 employees, including 209 employees who suffered of serious health problems; 30 died. In 2018, compared with 2017, the total number of victims of accidents at work increased by $17 \%$; the number of seriously injured remained virtually unchanged, and the death toll increased by $43 \%$. There has also been an increase number of workers with occupational diseases.

In 2018 , number of newly registered occupational patients was 1,697 , which is $19 \%$ more compared to 2017 [11]. Occupational diseases are most affected by age groups from 45 to 64 years, and this is important point, given the fact that the tendency for aging population is sharply expressed in Latvia, accordingly, the proportion of middle-aged and older workers is increased. Increase in working age leads to increase in the number of concomitant diseases, a decrease in the level of physical fitness, a combination of risk factors at work and an increase in the number of diseases associated with work. Given the shortage of human resources, deterioration of their quality is one of the obstacles to the innovative development of Latvia. Purpose of this article is based on analysis of the situation in the engineering and metalworking industries, to identify the dynamics of accidents and occupational diseases, to identify the characteristic types of occupational diseases, and to develop proposals for improving the situation by using the possibilities of health tourism.

\section{Materials and Methods}

In this process, author has completed:

- analysis of State Labor Inspectorate of Latvia on accidents at work, dynamics of occupational diseases, including among workers in the engineering and metalworking industries; causes of occupational diseases;

- analysis of data from the Latvian Association of Mechanical Engineering and Metalworking on the situation in the industry;

- study of the possibilities of SPA and Wellness tourism in reducing the number of occupational diseases and accidents at workplace, as well as general in improving the health of workers in the machine-building and metal-working industries.

\section{Results and discussion}

The number of accidents and deaths in the workplace in Latvia has increased over the past few years. According to Eurostat, Latvia ranks third place in EU in number of deaths in the workplace, second place only Luxembourg and Romania have. The vast majority of accidents at work in Latvia - $80 \%$ is fatal and $65 \%$ are severe, occur in industries such as construction, agriculture and forestry, transport and storage, as well as in manufacturing. Table 1 presents the data of the State Labor Inspectorate of Latvia on the number of accidents in certain sectors of engineering and metalworking.

Table 1. Number of accidents in selected sectors of engineering and metalworking in Latvia 


\begin{tabular}{|l|l|c|c|c|c|c|c|}
\hline \multirow{2}{*}{$№$} & ENGINEERING AND & \multicolumn{2}{|c|}{ TOTAL } & \multicolumn{4}{c|}{ INCLUDING } \\
\cline { 3 - 8 } & \multirow{2}{*}{\begin{tabular}{l} 
METALWORKING SECTOR \\
\cline { 3 - 8 }
\end{tabular}} & 2017 & 2018 & 2017 & 2018 & 2017 & 2018 \\
\hline 1. & Manufacture of basic metals & 9 & 12 & 0 & 1 & 0 & 0 \\
\hline 2. & $\begin{array}{l}\text { Manufacture of fabricated metal } \\
\text { products, except machinery and } \\
\text { equipment }\end{array}$ & 77 & 76 & 3 & 6 & 0 & 1 \\
\hline 3. & $\begin{array}{l}\text { Manufacture of electrical } \\
\text { equipment }\end{array}$ & 3 & 13 & 0 & 0 & 0 & 0 \\
\hline 4. & $\begin{array}{l}\text { Manufacture of machinery and } \\
\text { equipment n.e.c. }\end{array}$ & 9 & 16 & 1 & 0 & 0 & 0 \\
\hline 5. & $\begin{array}{l}\text { Manufacture of motor vehicles, } \\
\text { trailers and semi-trailers }\end{array}$ & 15 & 19 & 1 & 0 & 0 & 0 \\
\hline 6. & $\begin{array}{l}\text { Manufacture of other transport } \\
\text { equipment }\end{array}$ & 5 & 3 & 0 & 0 & 0 & 0 \\
\hline
\end{tabular}

Data generally indicate worsening situation in the industry. Accidents mainly occur due to non-compliance with labor protection rules or instructions, the use of incorrect or unacceptable working methods, or due to negligence of workers. In addition, alarming tendency towards an increase in the number of natural deaths in the workplace has been outlined in Latvia, in this case there is no influence of any risk factor for the work environment.

More people are suffering from occupational diseases. The main causes of occupational diseases are, firstly, unfavorable factors of the working environment and the labor process, and secondly, failure to conduct at all, or not conducting health checks on time. Table 2 shows the dynamics of workers numbers in certain sectors of the engineering and metalworking industries for which occupational disease was first established.

Table 2. The number of workers in the machine-building and metalworking industries who were first diagnosed with occupational disease

\begin{tabular}{|l|l|c|c|}
\hline № & Engineering and Metalworking Sector & 2017 year & 2018 year \\
\hline 1. & Manufacture of basic metals & 4 & 3 \\
\hline 2. & $\begin{array}{l}\text { Manufacture of fabricated metal products, except } \\
\text { machinery and equipment }\end{array}$ & 20 & 20 \\
\hline 3. & Manufacture of electrical equipment & 6 & 6 \\
\hline 4. & Manufacture of machinery and equipment n.e.c. & 2 & 3 \\
\hline 5. & Manufacture of motor vehicles, trailers and semi-trailers & 4 & 4 \\
\hline 6. & Manufacture of other transport equipment & 5 & 3 \\
\hline
\end{tabular}

The leading adverse factors in the production environment and labor process at engineering and metalworking enterprises that contribute to the occurrence of occupational diseases are the heating microclimate, light environment, noise, vibration, industrial dust and toxic substances in the air of the working area, the severity and intensity of work.

Vibration disease, occupational chronic sensorineural hearing loss, diseases of the musculoskeletal system from overvoltage and micro traumatization, occupational respiratory diseases (pneumoconiosis, occupational bronchitis) are among the most common occupational diseases at engineering enterprises.

A socially insured employee has the right to receive insurance compensation for the costs of treatment and rehabilitation if he has suffered from an accident at work or if he has been diagnosed with occupational disease, as a result of which temporary disability or disability has been established. The types of insurance compensation include reimbursement of additional expenses related to treatment, purchase of medicines, medical and social rehabilitation, etc. [12]. 
When choosing a place of rehabilitation after serious treatment, physical and emotional injuries, important factors are environment, the healing power of nature, a list of methods and services for rehabilitation, as well as the qualifications and experience of the staff. In addition, there is growing interest in non-invasive methods of treatment and recovery. In order to prevent a number of diseases, workers with long experience are recommended courses of preventive treatment 1-2 times a year. This situation leads to increase in the role of health tourism in reducing the number of occupational diseases and accidents. Tourism is increasingly perceived as a recreational component of human life, as a means of restoring the physical and mental strength of a person. In this regard, the role of health tourism has grown significantly, based on the recreational needs of a person for the expanded reproduction of physical, intellectual and emotional forces.

In Fig. 1, author proposed a scheme which reveals the essence and the ratio of the components of health tourism.

\begin{tabular}{|c|c|c|}
\hline & \multicolumn{2}{|c|}{$\begin{array}{l}\text { HEALTH TOURISM } \\
\text { Those forms of tourism focus on physical health, but } \\
\text { also improve mental and spiritual well-being and } \\
\text { increase people's ability to satisfy their own needs and } \\
\text { function better in the environment and society. }\end{array}$} \\
\hline $\begin{array}{l}\text { MEDICAL } \\
\text { TOURISM } \\
\text { Tourist trips made by } \\
\text { both residents and non- } \\
\text { residents in order to } \\
\text { receive medical services } \\
\text { undergo rehabilitation, } \\
\text { perform medical } \\
\text { procedures, operations } \\
\text { or preventive health } \\
\text { recovery. }\end{array}$ & $\begin{array}{l}\text { SPA-TOURISM } \\
\text { Tourist trips carried out } \\
\text { by both residents and } \\
\text { non-residents, the main } \\
\text { purpose of which is health } \\
\text { improvement, relaxation } \\
\text { and cosmetic body care } \\
\text { by obtaining mainly water } \\
\text { and other SPA-procedures } \\
\text { in tourist SPA- } \\
\text { destinations. }\end{array}$ & \multirow[t]{2}{*}{$\begin{array}{l}\text { WELLNESS TOURISM } \\
\text { Tourist trips carried out by both } \\
\text { residents and non-residents in } \\
\text { order to improve and balance all } \\
\text { the main components of human } \\
\text { life, including physical, mental, } \\
\text { emotional, professional, } \\
\text { intellectual and spiritual, through } \\
\text { participation in preventive, active, } \\
\text { life-promotingactivities, } \\
\text { suchasfitness, healthyeating, } \\
\text { relaxation, pampering and he } \\
\text { alingtreatments. }\end{array}$} \\
\hline & & \\
\hline
\end{tabular}

Fig. 1. Essence and ratio of components of health tourism

Medical tourism is actively developing in Latvia. There is number of institutions providing rehabilitation services, for example, Jaunkemeri resort rehabilitation center, where modern diagnostic and treatment methods combined with the use of natural resources (hydrogen sulfide, bromine mineral water, therapeutic mud, etc.) for the treatment of a number of diseases, including and characteristic for workers in the engineering and metalworking industries, in particular, diseases of the musculoskeletal system. Vaivari National Rehabilitation Center provides in-patient medical rehabilitation in six rehabilitation programs. These programs provide for early multi-professional rehabilitation of patients with severe functional disabilities and provide dynamic patient monitoring. The rehabilitation center „Līgatne” offers medical rehabilitation services to patients after various diseases, for example, after operations, back problems, diseases of the osteoarticular or cardiovascular system, problems caused by stress, etc. For the purpose of rehabilitation and prevention of professional Latvians go to health resorts in neighboring Lithuania and Estonia, which successfully compete with Latvia infield of health tourism. In these conditions, it is necessary to intensify the work of restoring previously functioning 
and creating new resorts in Latvia, since resorts are important part of health tourism. In some countries, resort is associated more with leisure, relaxation and entertainment, but in Baltic countries it is wellness and rehabilitation aspect of the resorts which is very important.

Significant contribution to improuve the quality of workers life with occupational diseases, as well as to reduce the rates of occupational diseases and accidents at the workplace, can be achieved by introducing Wellness into the minds of both workers and employers. Wellness is, first of all, a person's choice, his desire to take responsibility for the quality of his own life, this is a conscious decision to create a healthy lifestyle $[13,14]$. The absence of the disease, which modern medicine is aimed at, does not bring a person well-being, does not mean the quality of life. The Wellness concept is aimed at helping people achieve a higher level of health, a better quality of life, regardless of their current state of physical health. According to J. Travis, even a physically ill person can live a quality life.

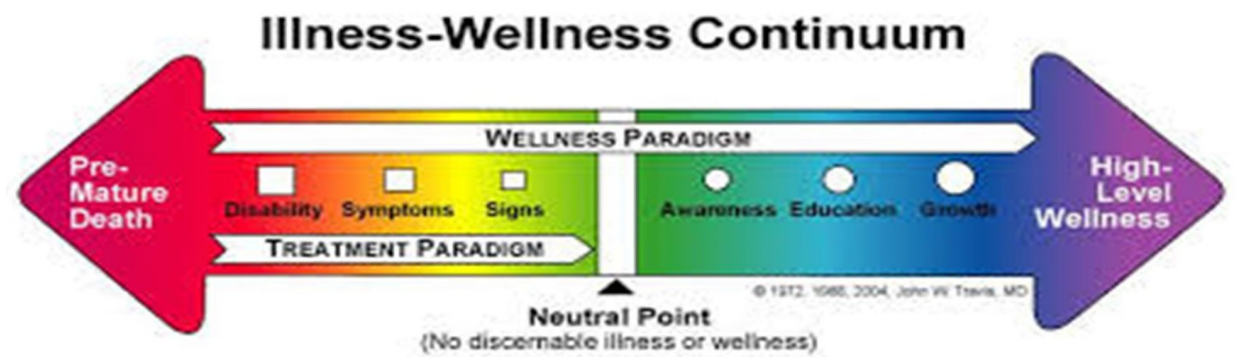

Fig. 2. Continuum Illness- Wellness [15]

Just as there are degrees of illness, there are degrees of well-being, and wellness services should be focused on identifying the causes of well-being, and not diseases. Seekers of their own well-being can apply for services that are very similar to the medical services used by patients in a regular hospital, but with motive of using their potential to improve their quality of life. Although the impact of the health resorts is mainly related to their atmosphere, environment or location, this is not enough to achieve a sense of wellbeing, so the spa needs to take care of what contribution it needs to make its clients feel a sense of psychological, spiritual or emotional well-being in addition to physical, being at this resort. To this end, the Wellness Center is often an alternative space in which you can engage in introspection without stress and distracting from home. Adding a variety of wellness programs or treatments can further encourage person to travel from selfknowledge to rejuvenation, living longer and happier.

Despite the existing terminological differences, blurred boundaries between medical, Wellness and SPA tourism, which leads to diverging approaches to accounting for health trips, general tendency for the growth of health tourism in general is expressed. In SPA and Wellness tourism, this trend is clearly reflected. Table 3 presents data on health tourism trips in Baltic countries in 2014.

Table 3. Health tourism trips in Baltic countries, 2014 [16]

\begin{tabular}{|c|l|l|l|l|l|l|l|l|}
\hline & \multicolumn{2}{|l|}{ Health tourism trips, mIn. } & $\begin{array}{l}\text { The share of overall } \\
\text { health tourism trips } \\
\text { in\% of all tourist } \\
\text { departures }\end{array}$ & $\begin{array}{l}\text { Revenues, billion } \\
\text { euros }\end{array}$ & $\begin{array}{l}\text { Costs, } \\
\text { billion } \\
\text { euros }\end{array}$ \\
\cline { 2 - 7 } & \multicolumn{2}{|c|}{$\begin{array}{l}\text { Internationa } \\
\text { Local } \\
\text { travel }\end{array}$} & $\begin{array}{l}\text { Internatio } \\
\text { nal } \\
\text { Arrivals }\end{array}$ & $\begin{array}{l}\text { Intecal+ } \\
1 \text { departures } \\
\text { Internationa } \\
1 \text { departures }\end{array}$ & $\begin{array}{l}\text { Internatio } \\
\text { nal } \\
\text { Arrivals }\end{array}$ & $\begin{array}{l}\text { Local } \\
\text { arrivals }\end{array}$ & $\begin{array}{l}\text { Interna } \\
\text { tional } \\
\text { arrivals }\end{array}$ & $\begin{array}{l}\text { Internatio } \\
\text { nal } \\
\text { Shipping }\end{array}$ \\
\hline
\end{tabular}




\begin{tabular}{|l|l|l|l|l|l|l|l|l|}
\hline & & & & & & & & Costs \\
\hline Estonia & 0.08 & 0.15 & 0.04 & $3.0 \%$ & $5.3 \%$ & $€ 0.01$ & $€ 0.07$ & $€ 0.02$ \\
\hline Latvia & 0.47 & 0.05 & 0.20 & $14.3 \%$ & $2.8 \%$ & $€ 0.05$ & $€ 0.03$ & $€ 0.11$ \\
\hline $\begin{array}{l}\text { Lithua } \\
\text { nia }\end{array}$ & 0.15 & 0.05 & 0.10 & $5.7 \%$ & $2.3 \%$ & $€ 0.04$ & $€ 0.03$ & $€ 0.05$ \\
\hline
\end{tabular}

According to data, Latvia is leading among Baltic countries in number of domestic trips within the framework of health tourism, which indicates an increase to attention of the state residents to its health.

By 2014, more than half of employers around the world are using staff strategies based on the concept of a healthy lifestyle, and third are investing in full-blown Wellness programs. Corporate Wellness-programs form the personnel's attitude to health, staff receives practical knowledge and skills to maintain and strengthen health. As part of the corporate fitness program, employees participate in medical and preventive measures aimed at general improvement of body and the prevention of chronic, including occupational, diseases. Wellness staff is potential Wellness tourist.

Medical tourism involves people traveling specifically to gain access to medical treatment. People travel for Wellness tourism to maintain or improve their personal health and well-being. SPA tourism focuses on healing, relaxation or body decoration, which is preventive and / or therapeutic. All three categories of health tourism are in demand for treatment and rehabilitation after industrial injuries or occupational diseases, as well as for preventive purposes.

\section{Conclusion}

To reduce number of dishonest cases and occupational diseases in the engineering and metalworking industries, it is necessary to strengthen the cooperation of all interested parties - the state, business, the tourism industry and directly the employees of enterprises. The state should provide comprehensive support to the development of health tourism, Latvian destinations of health tourism - not to see only foreign tourists as target audience, but to pay attention to the possibilities of attracting domestic tourists - employees of Latvian enterprises; business - within the framework of staff incentives and motivation, include preferential or free trips to the health complex or resort to the enterprise's social services package; as innovation in personnel management, it is possible to define the introduction of the Wellness concept in personnel strategies. And, of course, the staff themselves must change their attitude to their health and realize that, first of all, the person himself is responsible for his physical, mental and spiritual health.

\section{References}

1. R. Pukala, E3S Web of Conferences, 105, 04015 https://doi.org/10.1051/e3sconf/201910504015

2. R. Pukala, M. Petrova, E3S Web of Conferences, 105, 04034 (2019) https://doi.org/10.1051/e3sconf/201910504034

3. M. Petrova, M.Tepavicharova, L. Dikova, E3S Web of Conferences Volume 41, 04017 (2018) https://doi.org/10.1051/e3sconf/20184104017.

4. M. Petrova, I. Buzko, Yu. Dyachenko 17th International Scientific Conference ERDev, 1102 (2018) DOI: 10.22616/ERDev2018.17.N170 
5. N. Kurmanov, M. Petrova, S. Suleimenova, E3S Web of Conferences, 105, 04045 (2019) https://doi.org/10.1051/e3sconf/201910504045

6. I. Gryshova, M. Petrova, M. Tepavicharova, A. Diachenko, T. Gutsul, $\begin{array}{lllll}\text { Entrepreneurship } \quad \text { and } \quad \text { Sustainability, } & \mathbf{7 1}, \quad 690 & \text { (2019) }\end{array}$ http://doi.org/10.9770/jesi.2019.7.1(49)

7. R. Pukala, Engineering Management in Production and Services, 8, 3, 43 (2016)

8. Vazov R. Inovative Approaches to Insurance Company Cash Flow Management (contemporary theoretical aspects) (VUZF Publishing House "St. Grigorii Bogoslov", Sofia, 2019)

9. T. Lazarova, V. Zhelyazkova, R. Vazov, Proceedings of International Conference for Entrepreneurship, Innovation and Regional Development ICEIRD 2015, University of Sheffield, 275 (2015)

10. A. Islamgaleyev, Innovation Processes in the context of Globalization of the World Economy: Challenges, Trends, Prospects (IPEG-2018) (2018)

11. Valsts darba inspekcija. 2018. Gada darbības pārskats (2019) Retrieved from: http://www.vdi.gov.lv/files/2018 gada darbibas parskats.pdf

12. The State Social Insurance Agency (2018). Insurance Indemnity Related to Accident at Work or Occupational Disease. - https://www.vsaa.gov.lv/en/services/foremployees/accident-at-work-or-occupational-disease/insurance-indemnity-related-toaccident-at-work-or-occupational-disease/

13. D. B. Ardell, High level wellness: an alternative to doctors, drugs, and disease. (Rodale Press, Emmaus, PA, 1977)

14. M. Petrova, Nadiya Dekhtyar, Oleksii Klok and Olha Loseva. Problems and Perspectives in Management, 16(4), 259 (2018) doi:10.21511/ppm.16(4).2018.22

15. J. Travis, R. Ryan, Wellness Workbook: How to Achieve Enduring Health and Vitality. (Celestial Arts, Berkeley? 2004).

16. Mainil, E. Eijgelaar, J. Klijs, J. Nawijn, P. Peeters Research for TRAN Committee Health tourism in the EU: a general investigation, European Parliament, Policy Department for Structural and Cohesion Policies, Brussels. (2017) Retrieved from: http://www.europarl.europa.eu/RegData/etudes/STUD/2017/601985/IPOL_STU(2017 $\lcm{601985 \text { EN.pdf }}$

17. A. Islamgaleyev, Target client group analysis at "Kazpromkomplex" LLP. (Minzu University of China «Scientific research of the SCO countries: synergy and integration», China, 2018)

18. T. Odinokova, Tourism cluster as a form of innovation activity. Economics. Ecology. Socium, 3 (2), 1 (2019) 